\title{
Cultural Resources Inventory and Evaluation for Science City, Conducted for Expansion of the Maui Space Surveillance Site, Haleakala, Maui, Hawaii
}

\author{
J. C. Chatters
}

July 1991

Prepared for the U.S. Air Force

Headquarters Space Systems Division

Air Force Systems Command

Los Angeles Air Force Base

under a Related Services Agreement

with the U.S. Department of Energy

Contract DE-AC06-76RLO 1830

Pacific Northwest Laboratory

Operated for the U.S. Department of Energy

by Battelle Memorial Institute 


\title{
DISCLAIMER
}

This report was prepared as an account of work sponsored by an agency of the United States Government. Neither the United States Government nor any agency thereof, nor Battelle Memorial Institute, nor any of their empioyees, makes any warranty, expressed or implied, or assumes any legal liability or responsibility for the accuracy, completeness, or usefulness of any information, apparatus, product, or process disclosed, or represents that its use would not infringe privately owned rights. Reíerence herein to any specific commercial product, process, or service by trade name, trademark, manufacturer, or olherwise does not necessarily constitute or imply its endorsement, recommendation, or favoring by the United States Government or any agency thereof, or Battelle Memorial Institute. The views and opinions of authors expressed herein do not necessarily state or reflect those of the United States Covernment or any agency thereof.

\author{
PACIFIC NORTHWEST LABORATORY \\ operated by \\ BATTELLE MEMORIAL INSTITUTE \\ for the \\ UNITED STATES DEPARTMENT OF ENERGY \\ under Contract DE-ACO6-76RLO 1830
}

Printed in the Uniled States of America

Available to DOE and DOE contractors from the

Office of Scientific and Technical Information, P.O. Box 62, Oak Ridge, TN 37431; prices available from (615) 576-8401. FTS 626-8401.

Available to the public from the National Technical information Service, U.S. Department of Commerce, 5285 Port Royal Rd., Springfield, VA 22161. 
CULTURAL RESOURCES INVENTORY AND EVALUATION FOR SCIENCE CITY, CONDUCTED FOR EXPANSION OF THE MAUI SPACE SURVEILLANCE SITE, HALEAKALA, MAUI, HAWAII

\author{
J. C. Chatters
}

July 1991

Prepared for

U.S. Air Force

Headquarters Space Systems Division

Air Force Systems Command

Los Angeles Air Force Base

under a Related Services Agreement

with the U.S. Department of Energy

Contract DE-AC06-76RLO 1830

Pacific Northwest Laboratory

Richland, Washington 99352 


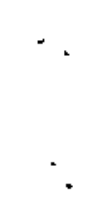




\section{SUMMABY}

As part of the environmental assessment process for the proposed modifications to the U.S. Air Force Maui Space Surveillance Site, an archaeological survey was conducted of Science City, an observatory complex on a summit of Haleakala Mountain, Island of Maui, Hawaii. Inspection of the 3.1 ha facility revealed four archaeological sites, designated 50-11-2805 through 50-11-2808. All consist of one or more temporary, probably single-person shelters with leveled floors and walls of stacked stones. Review of the literature and discussions with state officials resulted in a finding that these sites meet the criteria for nomination to the National Register of Historic Places.

Construction is not expected to have a direct effect on the sites. Activity in the vicinity of the sites is considered to have an indirect effect, although not a negative one. A finding of no adverse effect is recommended. 


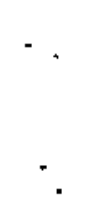


CONTENTS

SUMMARY $\ldots \ldots \ldots \ldots \ldots \ldots \ldots \ldots \ldots \ldots \ldots \ldots$ iii

1.0 INTRODUCTION AND PROJECT BACKGROUND $\ldots \ldots \ldots \ldots \ldots$

2.0 HISTORICAL AND ARCHAEOLOGICAL BACKGROUND

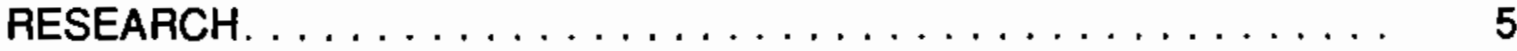

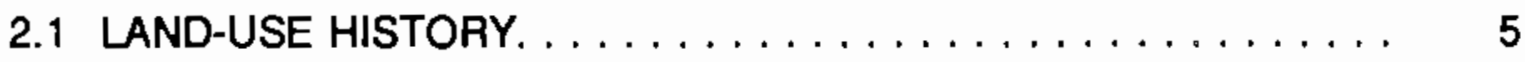

2.2 PREVIOUS ARCHAEOLOGICAL RESEARCH IN THE PROJECT AREA $\ldots \ldots \ldots \ldots \ldots \ldots \ldots \ldots \ldots \ldots \ldots$

2.3 KNOWN ARCHAEOLOGICAL SITES IN THE AHUPUA'A OF PAPAANUI AND NEARBY CRATER RIM $\ldots \ldots \ldots \ldots \ldots 6$

3.0 FIELD SURVEY AND THE CULTURAL RESOURCES RECORDED $\ldots . .9$

3.1 SITE $50-11-2805 \ldots \ldots \ldots \ldots \ldots \ldots \ldots \ldots \ldots \ldots$

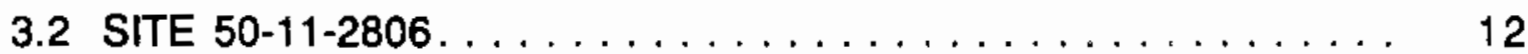

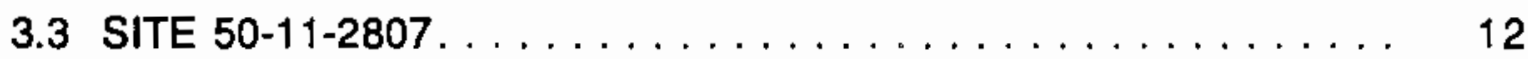

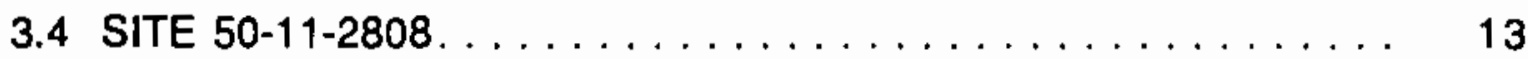

4.0 EVALUATION AND FINDINGS OF EFFECT AND

ADVERSE EFFECT $\ldots \ldots \ldots \ldots \ldots \ldots \ldots \ldots \ldots \ldots \ldots \ldots$

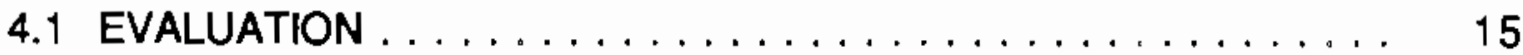

4.2 FINDINGS OF EFFECT AND ADVERSE EFFECT. . . . . . . . . 16

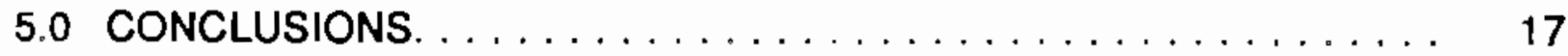

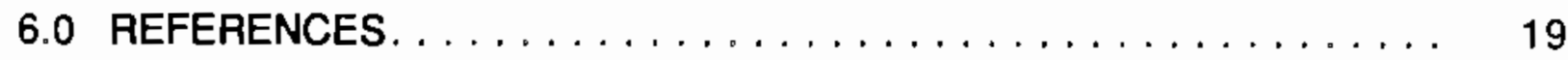




\section{EIGURES}

1 Location of the Maui Space Surveillance Site on the Island of Maui, Hawaii. . . . . . . . . . . . . . . . . . . . 2

2 Proposed New Boundaries and Construction at the Maui Space Surveillance Site ....................... 3

3 Alternative Sites for the Proposed AEOS Facility on Kolekole Hill . . . . . . . . . . . . . . . . . . . . . . . . 4

4 Locations of Archaeological Sites 50-11-2805 through 50-11-2808 around the Rim of Kolekole Hill in Relation to Existing and Proposed MSSS Facilities. . . . . . . . . . . . 10

5 Sketches of the Temporary Shelter at Site $50-11-2805 \ldots \ldots \ldots 11$

\section{IABLES}

1 Characteristics of Features in Site $50-11-2807 \ldots \ldots \ldots \ldots 13$

2 Features Comprising Site $50-11-2808 \ldots \ldots \ldots \ldots \ldots \ldots \ldots . \ldots \ldots$ 


\subsection{INTRODUCTION AND PROJECT BACKGROUND}

The U.S. Air Force (USAF) operates the Maui Space Surveillance Site (MSSS) on a summit of Haleakala on the island of Maui, Hawaii $\left(20^{\circ} 42^{\prime} 30.5^{\prime \prime} \mathrm{N}\right.$, $156^{\circ} 15^{\prime} 28.7^{\prime \prime} \mathrm{W}$; Figure 1). The site occupies 1.2 ha ( 3 acres) inside the University of Hawaii's observatory plot known as Science City. Increasing operations and research and development requests for use of the MSSS have resulted in a need to expand the infrastructure of the site. In response to these demands, the USAF proposes expanding the MSSS boundary within Science City to encompass 3.1 ha ( 7.7 acres) to support additional facilities, install new telescopes, and improve site access. Proposed construction includes building a warehouse and a maintenance shop, upgrading fuel-storage facilities, widening of the access road, expanding parking areas, expanding the utility substation, and installing an advanced electro-optical telescope (AEOS) (Figure 2).

Construction of the AEOS will result in the greatest impact to the land surface, since most other structures are either small or inside the original boundaries of the facility. The AEOS is proposed for construction on a mesa-like eminence known as Kolekole Hill (Figure 3 ) and will include a $9-\mathrm{m}$ by $37-\mathrm{m}$ below-ground laboratory and overlying 9-m-diameter dome. A $740-\mathrm{m}^{2}$ paved parking/service area will also be developed.

As part of the environmental assessment process, the USAF contracted with the Pacific Northwest Laboratory (PNL)(a) to conduct an archaeological survey of Science City and to evaluate any cultural resources that might be found there. The effort consisted of literature review and field survey components, results of which are described in this report.

(a) PNL is operated for the U.S. Department of Energy by Battelle Memorial Institute. 


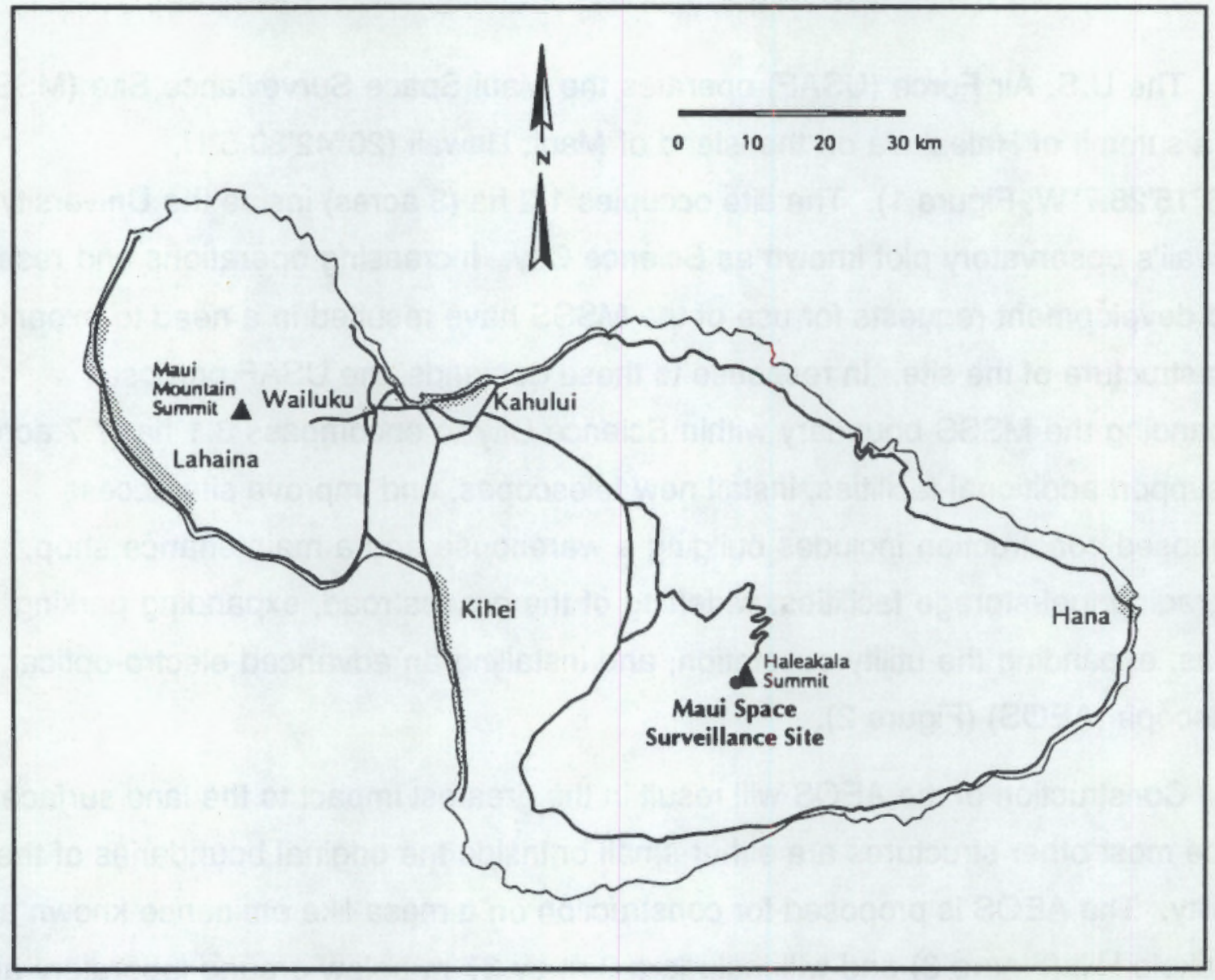

FIGURE 1. Location of the Maui Space Surveillance Site on the Island of Maui, Hawaii 


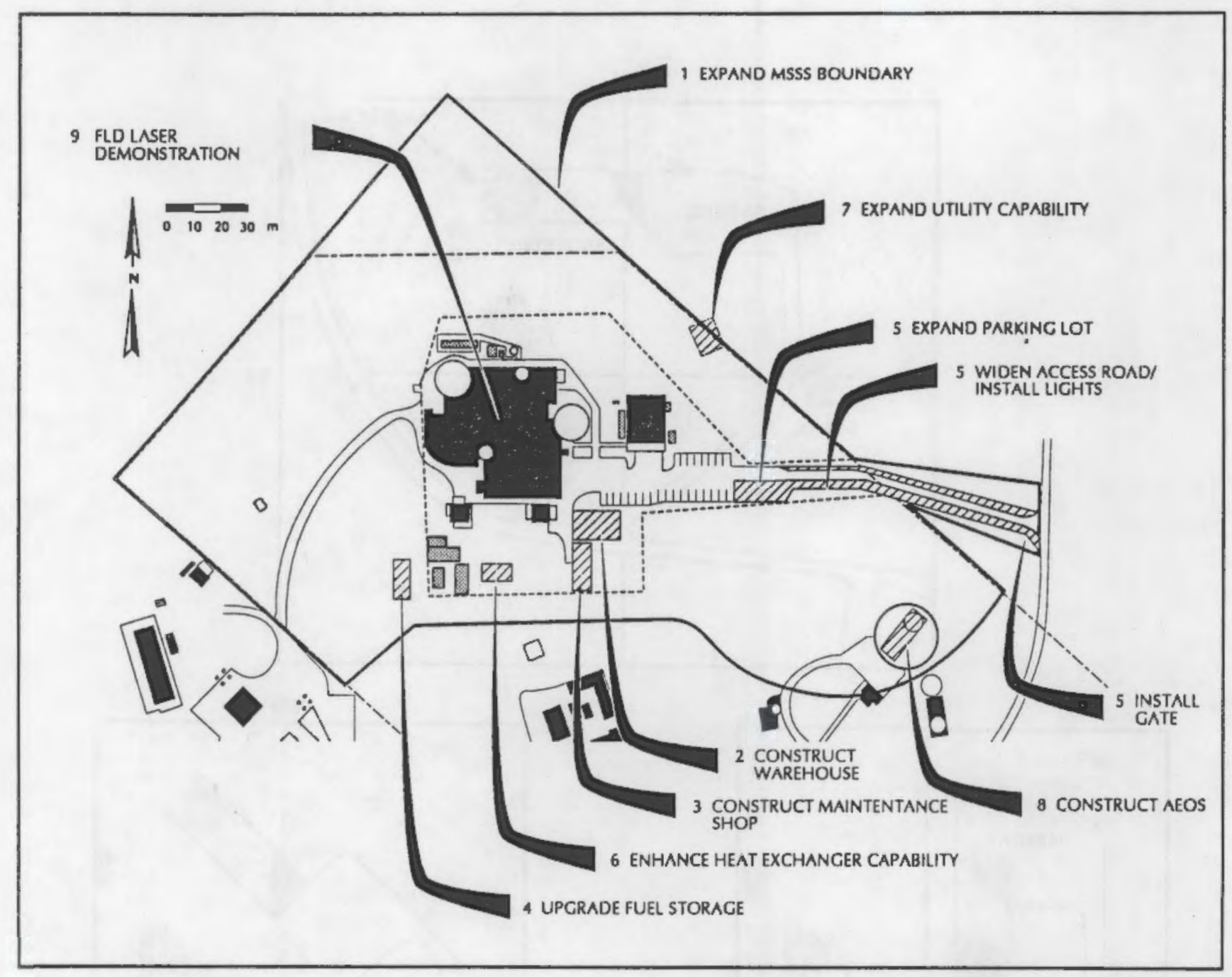

FIGURE2. Proposed New Boundaries and Construction at the Maui Space Surveillance Site 

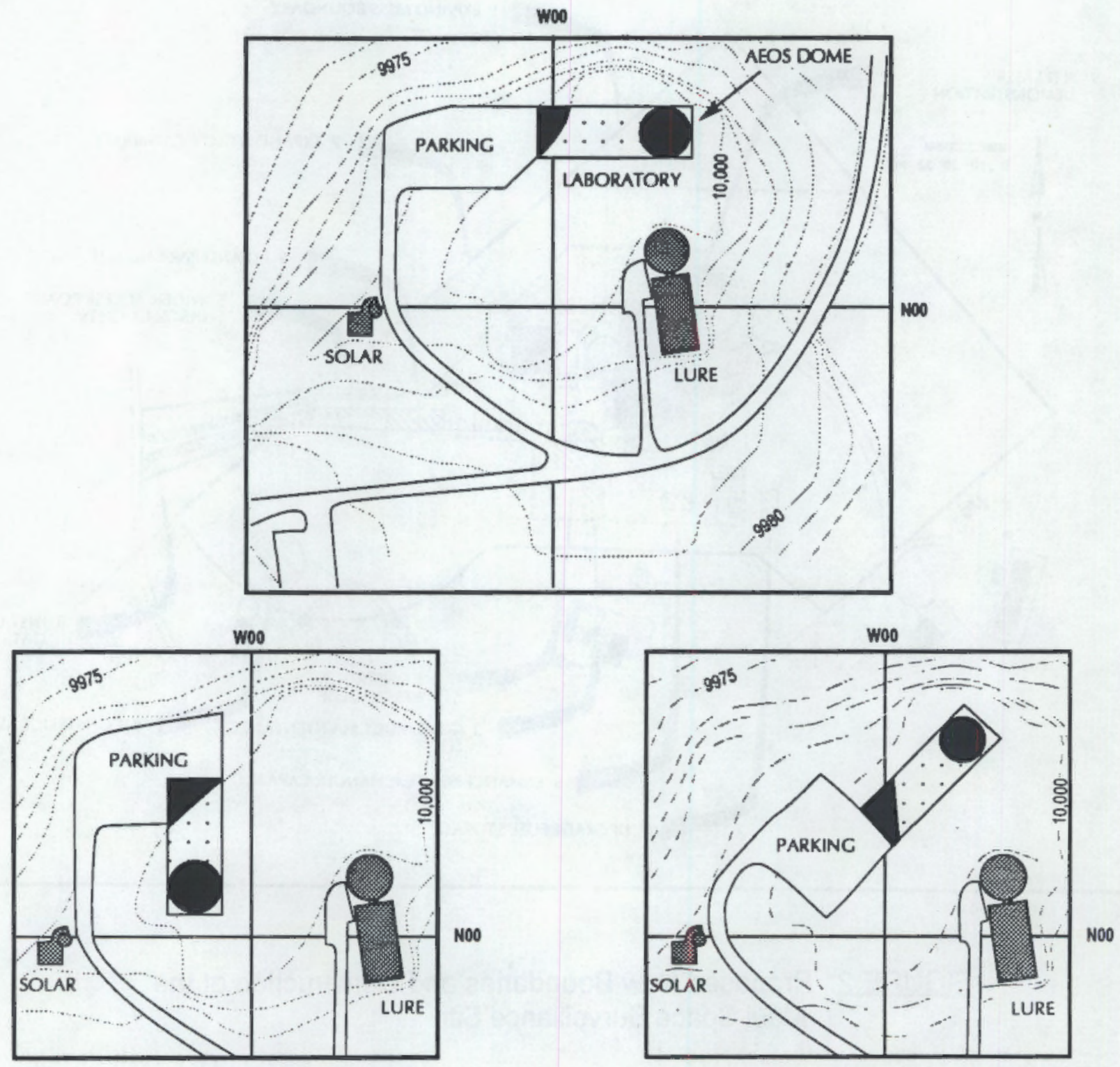

FIGURE 3. Alternative Sites for the Proposed AEOS Facility on Kolekole Hill. Sites are $A$ through $C$, starting counterclockwise from the top. Site $A$ is the preferred alternative. 


\subsection{HISTORICAL AND ARCHAEOLOGICAL BACKGROUND RESEARCH}

Literature review consisted of inspecting archaeological reports and site and landuse records in the office of the Historic Sites Section (HSS), State of Hawaii Division of State Parks, Outdoor Recreation and Historic Sites, in Honolulu. The purposes of this review were to establish a history of land use and historic property patterns, to learn the history of archaeological studies in the area, and to learn the types and distributions of archaeological sites found in the project area and environs.

\subsection{LAND-USE HISTORY}

The MSSS is located in the ahupua'a (traditional land division) of Papaanui in the Makena District. Papaanui is a discontinuous ahupua'a, with a narrow, wedgeshaped portion extending from the west coast in what is now the town of Kihei upslope to a low summit known as Keonenelu. The upper portion of the ahupua'a begins along a southwest-trending ridge line to the summits named Kolekole, Red Hill, and Pakaoao. It then crosses the crater floor, encompassing the cinder cones of Kalua $O$ Ka Oo, Kamoalii, and Puu O Maui, to Puu Kumu on the opposite rim. Then it extends some two miles (over three kilometers) along Kalapawili Ridge, ending at Pahaku Palaha. No land grants have been recorded in the Hawaii Real Estate Atlas in the vicinity of the project area. Evidently the land has been in government hands continuously since the modern land-management system was instituted.

\subsection{PREVIOUS ARCHAEOLOGICAL RESEARCH IN THEPROJECT AREA}

Six archaeological surveys have included parts of this ahupua'a. Soehren (1963) included parts of it in his reconnaissance of East Maui and Haleakala National Park. Surveys for a goat fence, a road realignment, and a water line, all in the vicinity of the Haleakala overlook, were conducted by Paul Rosendahl in the 1970s, and a survey of a new building for the Ground Electro Optical Deep Space Surveillance 
facility was conducted by Hamilton Aho of Hawaii Marine Research.(a) Only one survey reports activity in the lower portion of the ahupua'a (Bath 1983). More recently, Gary Somers, archaeologist for Haleakala National Park, has conducted reconnaissance along the crater rim, but no report is yet available on that work. Margaret Rosendahl (1978) has written an overview of the archaeological resources of Haleakala National Park that provides background on the kinds of archaeological properties known from the crater rim.

\subsection{KNOWN ARCHAEOLOGICAL SITES IN THE AHUPUA'A OF PAPAANUI AND NEARBY CRATER RIM}

Archaeological site records have been maintained separately by the State of Hawaii and by the Bernice P. Bishop Museum, which formerly conducted or coordinated most archaeological studies. The archaeological site records of the State of Hawaii (assigned numbers 50-11-\#) list two sites in the upper portion of Papaanui Ahupua'a and three in the lower. Bishop Museum records list an additional 38 sites (assigned numbers 50-Ma-MH-\#), although there is some overlap between the two groups.

Three sites (50-11-2254, -2255 , and -3100$)$ are recorded for lowland portions of the ahupua'a. These consist of two walls and a disturbed shell midden, respectively.

Twenty sites are reported for the crater rim, most of them in two clusters. One cluster is in the vicinity of Pakaoao (as known as White Hill), where Paul Rosendahl recorded 16 stone shelters (sites $50-\mathrm{Ma}-\mathrm{MH}-52$, and -61 through -64 ; the same sites are recorded in state files as 50-11-2511). The features in this site consist of roughly circular, single-course structures with cinder fill, measuring 2.0 to $3.5 \mathrm{~m}$ in diameter. The second concentration of sites is near Kilohana, a summit north of the Haleakala overlook. Twelve sites are in this group, including six cairns (ahu; numbers 50-Ma-Mh$76,-78$ through $-80,-82$, and -83 ), a platform of angular stones measuring roughly 4 by

(a) This information is reported in a letter from Hamilton Aho, Hawaii Marine Research, to Clarence Fuji, U.S. Army Corps of Engineers, dated April 8, 1980. 
2 by $0.5 \mathrm{~m}$ (50-Ma-MH-75), and shelters (50-Ma-MH-77, -81 , and -84 through -86$)$. Shelters include low, circular structures, like those at Pakaoao; walls connecting naturally placed boulders; and $\mathrm{C}$-shaped enclosures. Additional sites are shelters incorporating boulders at Kolekole Hill (50-Ma-MH-60), another cairn on the crater rim (50-Ma-MH-74), and an adze quarry and workshop complex (50-11-2510). Site 50-112510 is named Kalahaku Pali Adz Quarry and includes a cave, two rock shelters, and associated adze blanks and scatters of chipping debris.

Sites in the crater floor are associated with a trail (50-Ma-MH-11) that crosses the crater from east to west. Site $50-\mathrm{Ma}-\mathrm{MH}-10$ is a concentration of 63 shelters and 63 cairns along the trail, and is called Keahoukholu, or "heap of the traveler." Farther to the east along the trail, sheltered by the cinder cones named Halalii, Puu Nane, and Puu Mamane, is another concentration of features (50-Ma-MH-21 to -31). These features are two cairns and rectangular or T-shaped platforms of various sizes. The cairns are interpreted as a marker (50-Ma-MH-22) and a grave (50-Ma-MH-31); the platforms are shrines or altars.

The final two recorded sites in the ahupua'a are located on Kalapawili Ridge. One (50-Ma-MH-39) is a cave and the other (50-Ma-MH-55) is a well-known burial place in the cinder cone of Ka'a'awa [shown as Kaluaaawa on the U.S. Geological Survey (USGS) map], where bodies were disposed of in a deep vertical shaft in the cone center.

Based on these reports and a review of other sites mentioned by Soehren (1963) and Margaret Rosendahl (1978), it appears that sites are primarily trails, platforms, adze quarries, caves, temporary shelters, or cairns. The distributions of site types vary with topographic location. Platforms, which are typically assigned religious significance, are located primarily on the crater floor (although one is reported on the crater rim). Adze quarries and associated stone workshop areas are found near outcroppings of fine-grained basalt, primarily to the north and east of the project area. Caves and temporary shelters are typically a part of workshop sites. Temporary shelters, consisting of low, rectilinear, or arcuate walls built against boulders or cliffs and having leveled floors, also occur on the crater rim, notably on the leeward (west) 
sides of rocky eminences such as Pakaoao, unassociated with workshops. Soehren attributes these shelters to warriors, sandalwood cutters, or, later, goat hunters. Sling stones found in shelter floors corroborate use by warriors. Simple shelters are also found in abundance in the middle of the crater floor, where they are thought to be way stations for travelers crossing the crater from east to west. A few caves also show use as temporary shelters. Cairns occur in a variety of locations and may be either graves or markers of various kinds. 


\subsection{EIELD SURVEY AND THE CULTURAL RESOURCES RECORDED}

The project area was surveyed by J. C. Chatters of PNL and A. Griffin of the State of Hawaii on December 10,1990. Survey consisted of first scanning the land surface to identify undisturbed areas, then carefully examining those areas for cultural features and artifacts. Observed cultural materials were described and mapped by tape and compass. Examples were photographed.

The project area and all land within more than a kilometer in all directions consists of bare volcanic cinder and basaltic bedrock. Vegetation is sparse in the extreme; only an unidentified succulent and a bunchgrass were observed in the area surveyed. Land surface visibility was, therefore, unobstructed. The only areas found to be undisturbed were portions of the north, west, and south perimeter of Kolekole Hill and adjacent level land to the northwest of the hill (Figure 4). The summit of the hill had been leveled and all other lower-lying areas had been extensively disturbed by modern observatory-related activities.

Four groups of cultural features and two associated artifacts were observed (Figure 4). Features included 23 temporary shelters built against rock outcroppings (Figure 5) and one short, low wall. All were found around the sides of Kolekole Hill, most (19) on the western side. Artifacts were a sling stone, found in the floor of one shelter, and a limpet (opihi) shell, found near another group of shelters. These finds are described briefly below; details are provided in the archaeological site records, available from the HSS. Two of the sites, 50-11-2805 and 50-11-2806, are inside the proposed new boundary of the MSSS. The other two lie to the west and south, outside the boundary.

\subsection{SITE $50-11-2805$}

This is a shelter (Figure 5) built against a low cliff face immediately below and $2 \mathrm{~m}$ west of the receiver dish on the northeast corner of Kolekole Hill. It consists of a 2.4-mlong arcuate wall, up to five stones and $90 \mathrm{~cm}$ high, trending northeastward from the cliff face. A gap, or entrance, exists at the northeast end of the wall. The floor between 


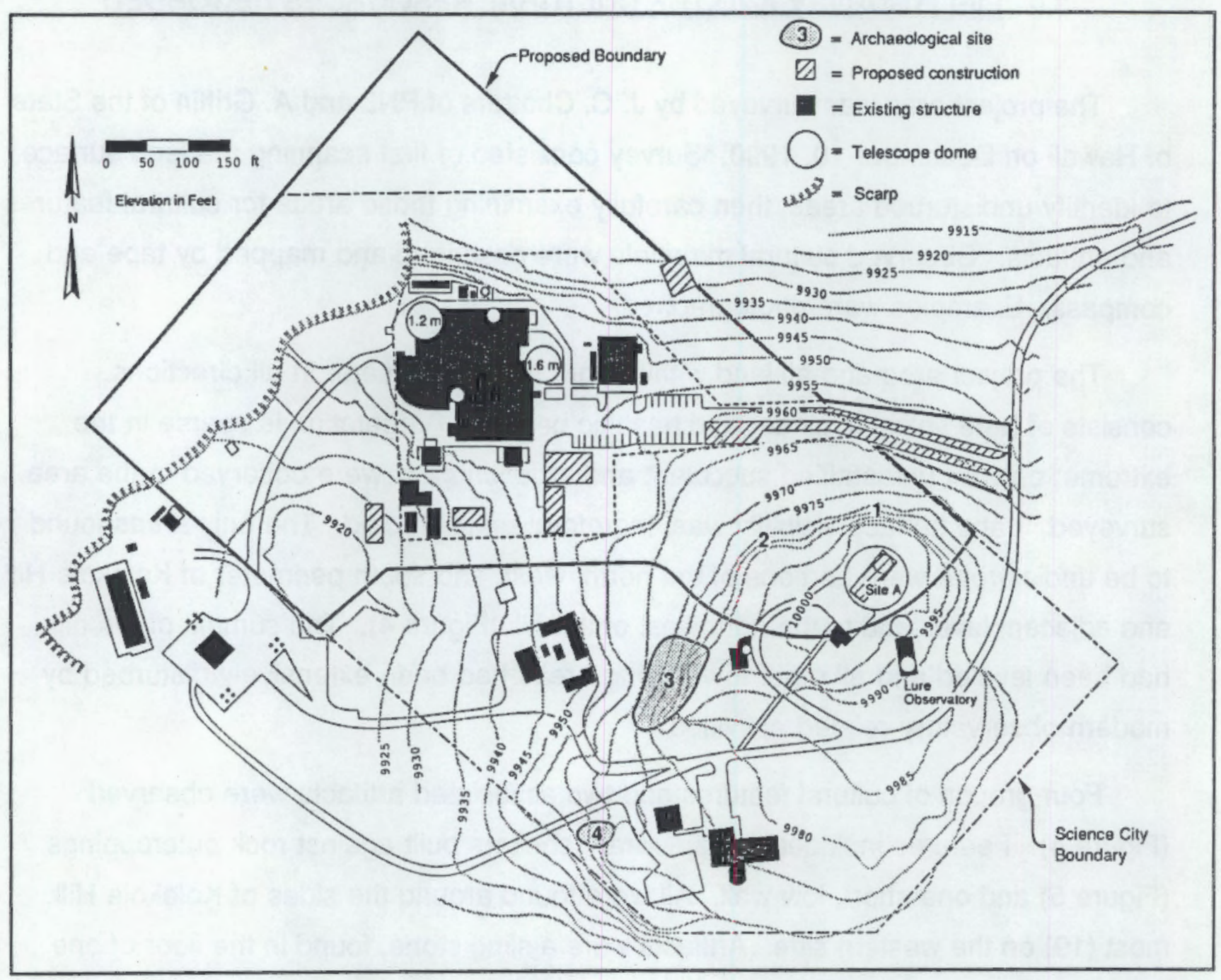

FIGURE 4. Locations of Archaeological Sites 50-11-2805 through 50-11-2808 (numbered 1 through 4) around the Rim of Kolekole Hill in Relation to Existing and Proposed MSSS Facilities 


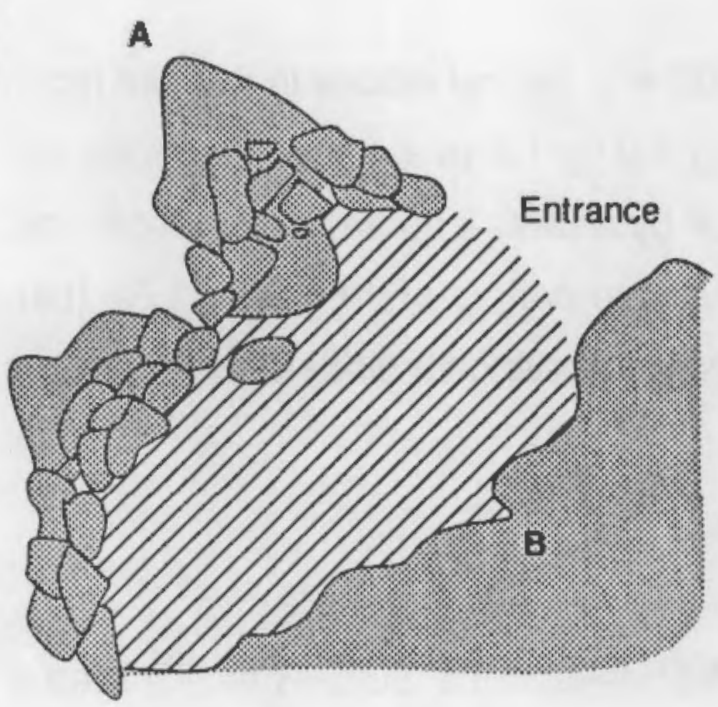

Plan view

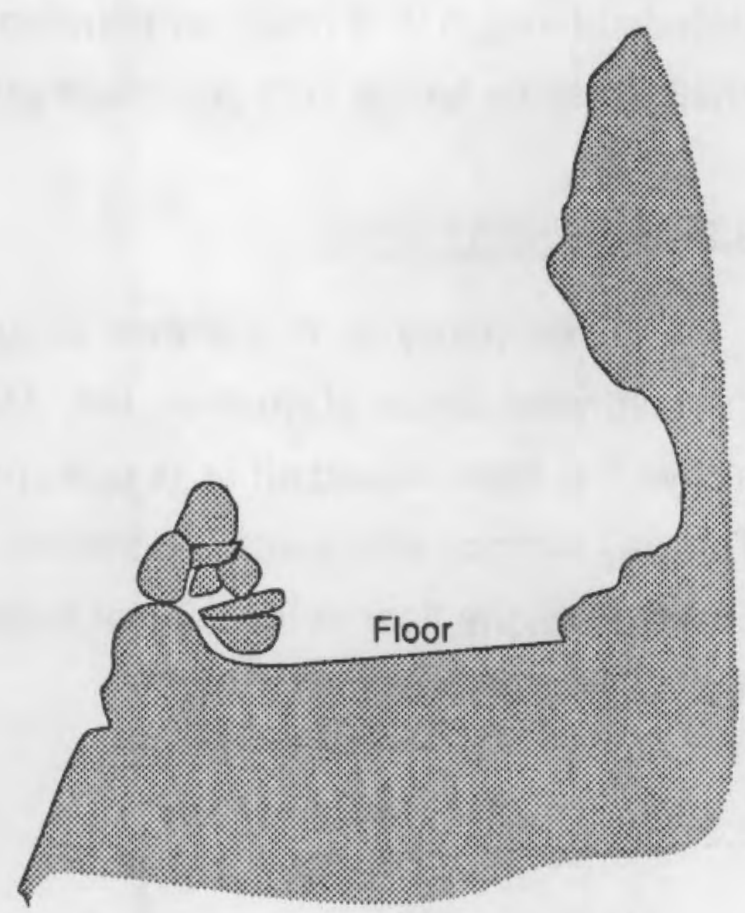

Cross section

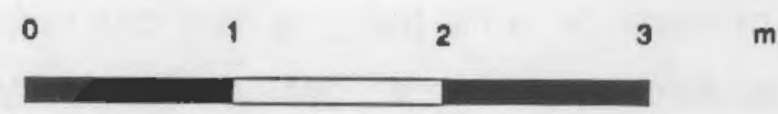

FIGURE 5. Sketches of the Temporary Shelter at Site 50-11-2805. This feature is typical of the shelters seen at all four sites, although it is better preserved than most of the others. 
the wall and cliff face has been leveled and is $2.3 \mathrm{~m}$ long by $1.4 \mathrm{~m}$ wide (at its widest point). Cinder blown from the hilltop covers the shelter floor. This material was troweled through to reveal finer-textured soil beneath, but no artifacts were found. This shelter was by far the best preserved of those observed.

\subsection{SITE $50-11-2806$}

Approximately $45 \mathrm{~m}$ due west of $50-11-2805$ is a natural alcove in the cliff face at the northwest corner of Kolekole Hill. Measuring 2.0 by $1.3 \mathrm{~m}$ at its leveled floor, the alcove has been closed off at its open north side by a three-course, $60-\mathrm{cm}$-high wall. The wall extends approximately one-fifth of the alcove perimeter, or $1.3 \mathrm{~m}$. Like that of 50-11-2805, the floor of this shelter is covered with wind-blown cinders; however, no test excavation was made.

\subsection{SITE $50-11-2807$}

Along a rubble-strewn slope of Kolekole Hill between the SOLAR facility (see Figure 3) and the Smithsonian Astrophysical Observatory is a concentration of 15 features ( $A$ through $O$ ), including one low wall and 14 temporary shelters. The shelters (Features $\mathrm{A}$ through $\mathrm{N}$ ) each consist of one or more low walls (ranging from one to five courses) built against bedrock or between boulders enclosing an oval-to-rectangular area with a leveled floor. Walls are made from angular lava, either stacked or set on edge, or sometimes both. Floors of sand-sized cinder are covered by coarser windblown cinder in most cases; the floors range from 1.4 to $3.4 \mathrm{~m}$ long and from 1.0 to $2.1 \mathrm{~m}$ wide. Dimensions of most shelters approached the mean of $2.41 \mathrm{~m}$ long by $1.47 \mathrm{~m}$ wide, or about the area needed for one person to sleep. The cluster is $42 \mathrm{~m}$ long and $15 \mathrm{~m}$ wide, with the greatest distance between adjacent group members being $3.5 \mathrm{~m}$. In some cases, stones were used to fill openings in the natural rock face. Hearth areas were not observed but may lie beneath the cinder covering of floors. Shelters occur from the rim of the hill to its base, approximately $4.5 \mathrm{~m}$ below. 
The isolated wall (Feature $O$ ) is $2 \mathrm{~m}$ long and five stones $(0.7 \mathrm{~m}$ ) high and is located on level ground $3 \mathrm{~m}$ west of the shelters. The dimensions of individual features are described in Table 1.

Only one artifact was found in this site. An 8-cm-diameter, water-rounded, spherical stone of a basalt porphyry was found on the floor of Feature J. This item is interpreted as a sling stone and indicates that at least one shelter was used by a traveling warrior.

\subsection{SITE $50-11-2808$}

This site, which covers an area of approximately 8 by $10 \mathrm{~m}$, is located at the southwest corner of Kolekole Hill, in the last outcrop of the west face of the hill, south of

IABLE 1. Characteristics of Features in Site 50-11-2807

\begin{tabular}{ccccc} 
Eeature & Description & Length.m & Width.m & Artifacts \\
\cline { 3 - 3 } A & shelter & 1.7 & 1.6 & \\
B & shelter & 2.4 & 1.3 \\
C & shelter & 2.3 & 1.6 \\
D & shelter & 2.3 & 1.2 & \\
E & shelter & 3.4 & 1.5 & \\
F & shelter & 2.5 & 1.0 \\
G & shelter & 2.4 & 1.5 \\
H & shelter & 3.0 & 1.6 \\
I & shelter & 2.5 & 1.5 \\
J & shelter & 2.3 & 1.4 & one sling stone \\
K & shelter & 3.0 & 1.3 \\
L & shelter & 1.4 & 1.3 \\
M & shelter & 2.3 & 1.7 \\
N & shelter & 2.3 & 2.1 \\
O & wall & 2.0 & 0.3
\end{tabular}


the road that links the Mees Observatory and the Federal Aviation Administration (FAA) facility. It consists of three shelters built one above the other against boulders and outcrops, in the same manner as described for the previous three sites. The leveled floors of sand-sized cinder material are rectangular to trapezoidal.

Dimensions are 1.7 to $2.1 \mathrm{~m}$ in maximum width and 2.3 to $3.3 \mathrm{~m}$ in length (Table 2). All walls are at least partially collapsed, but they range in height from the surface (a retaining wall used to build up a floor) to $40 \mathrm{~cm}$. A single limpet shell was found on the surface $2 \mathrm{~m}$ east of the central feature (Feature $\mathrm{C}$ ).

IABLE2. Features Comprising Site 50-11-2808

\begin{tabular}{|c|c|c|c|c|}
\hline Feature & Descriotion & Lenath. $m$ & Width m & Artifacts \\
\hline A & shelter & 2.4 & 1.7 & \\
\hline B & shelter & 2.3 & 2.1 & limpet shell \\
\hline c & shelter & 3.3 & 1.7 & \\
\hline
\end{tabular}




\subsection{EVALUATION AND FINDINGS OF EFFECT AND ADVERSEEFFECI}

Criteria set forth in 36 CFR 800 were applied to determine whether any of the sites described above might be eligible for nomination to the National Register of Historic Places and whether any adverse effects would occur as a result of the proposed actions.

\subsection{EVALUATION}

The Office of Hawaiian Affairs (OHA) was contacted on December 12, 1990, to obtain the Native Hawaiian perspective on site significance. Lynn Lee of the OHA expressed no special cultural interest in the sites, stating that ceremonial sites and graves were of the greatest cultural concern. She felt that there was no need to contact Native Hawaiians on Maui to discuss the sites. However, she expressed the interest of her agency in the preservation of Native Hawaiian sites as a matter of policy. This issue was also addressed with Annie Griffin of the HSS. Because the sites are all of the same kind and in approximately the same condition, they are addressed by a single evaluation.

Sites 50-11-2805 through 50-11-2808 all consist of one or more temporary, probably single-person shelters consisting of low walls and leveled floors built against natural rock formations and boulders. This is a common type of archaeological property on the rim and in the crater of Haleakala. Eleven other sites, including at least 84 shelters, have been recorded in the vicinity of the project area. Despite their frequency, shelter features in this setting have not been excavated. Although they are assumed to be travelers' shelters, their true function(s) and age distribution are unknown. Consequently, the four sites reported here have the potential to yield information important to the scientific understanding of prehistory, meeting criterion (d) of 36 CFR 800 for inclusion on the National Register. 


\subsection{FINDINGS OF EFFECT AND ADVERSE EFFECT}

Applying the Criteria of Effect and Adverse Effect (36 CFR 800.9), we find that the proposed actions may indirectly affect the setting of sites 50-11-2805 through 50-112808 by adding to the building complex that already exists near them. Under existing plans, however, the sites will not be directly altered. Because the new construction is in Science City, this does not constitute a change in the existing use or feeling and association of the locality. The characteristics of the sites that appear to make them eligible for the National Register of Historic Places--importance to scientific understanding of prehistory--will not be altered. Therefore, we find that the proposed activities will have no adverse effect on these four archaeological sites. 


\subsection{CONCLUSIONS}

Four archaeological sites were found during the archaeological survey of the land parcel known as Science City on the crest of Haleakala. Each consisted of one or more stone features known as shelters. These sites meet the criteria for eligibility to the National Register of Historic Places, under criterion (d), potential to yield important scientific information about prehistory. No evidence for any other historical use of the area was found. Two of the sites are located inside the proposed MSSS boundary but will not be physically altered by construction. Although construction will have an effect on the setting of these sites, it will have no adverse effect on the characteristics that make them eligible for the National Register of Historic Places. 


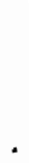




\subsection{REFERENCES}

Bath, J. E. 1983. Archaeological Survey of Makena Golf Course Well Sites, Tank Sites, and Access Roads. Prepared by J. Stephen Athens, Ph.D., Archaeological Consultant, for Seitu Hawaii, Inc., Wailuku, Maui.

Rosendahl, M. 1978. Preliminary Overview of Archaeological Resources at Haleakala National Park, Island of Maui. Bernice P. Bishop Museum, Honolulu, Hawaii.

Soehren, L. J. 1963. An Archaeological Survey of Portions of East Maui. Hawail. Bernice P. Bishop Museum, Honolulu, Hawaii. 

PNL-7769

UC-000

\section{DISTRIBUTION}

No. of

Copies

OFFSIIE

12 DOE/Otfice of Scientific and Technical Information

5 Dr. Charles Fine

Rockwell Power Systems

P.O. Box 758

Puunene, HI 96784

5 Maj. Thomas H. Lillie

Headquarters Space Division

Air Force Systems Command

Box 92960

Los Angeles AFB, CA 90009-2960
No. of

Copies

ONSITE

DQE. Richland Field Office

D. S. Trader

17 Pacific Northwest Laboratory

C. A. Brandt (3)

J. C. Chatters (3)

J. W. Falco

L. K. Grove

P. C. Hays

P. J. Mellinger

L. E. Rogers

Technical Report Files (5)

Publishing Coordination

Distr.1 
.

. 